\title{
PENGARUH PARTISIPASI ANGGARAN, SISTEM KEUANGAN DESA, PRINSIP- PRINSIP GOOD GOVERNANCE DAN PEMBERDAYAAN MASYARAKAT TERHADAP KUALITAS ANGGARAN PENDAPATAN DAN BELANJA DESA
}

\author{
Rosalia Sihotang $^{1}$, Sri Yuni ${ }^{*}$, Ferry Christian ${ }^{\text {* }}$ \\ 1,2,3 Fakultas Ekonomi dan Bisnis, Universitas Palangka Raya \\ *Corresponding: sri.yuni@,feb.upr.ac.id, ferrychristian@,feb.upr.ac.id
}

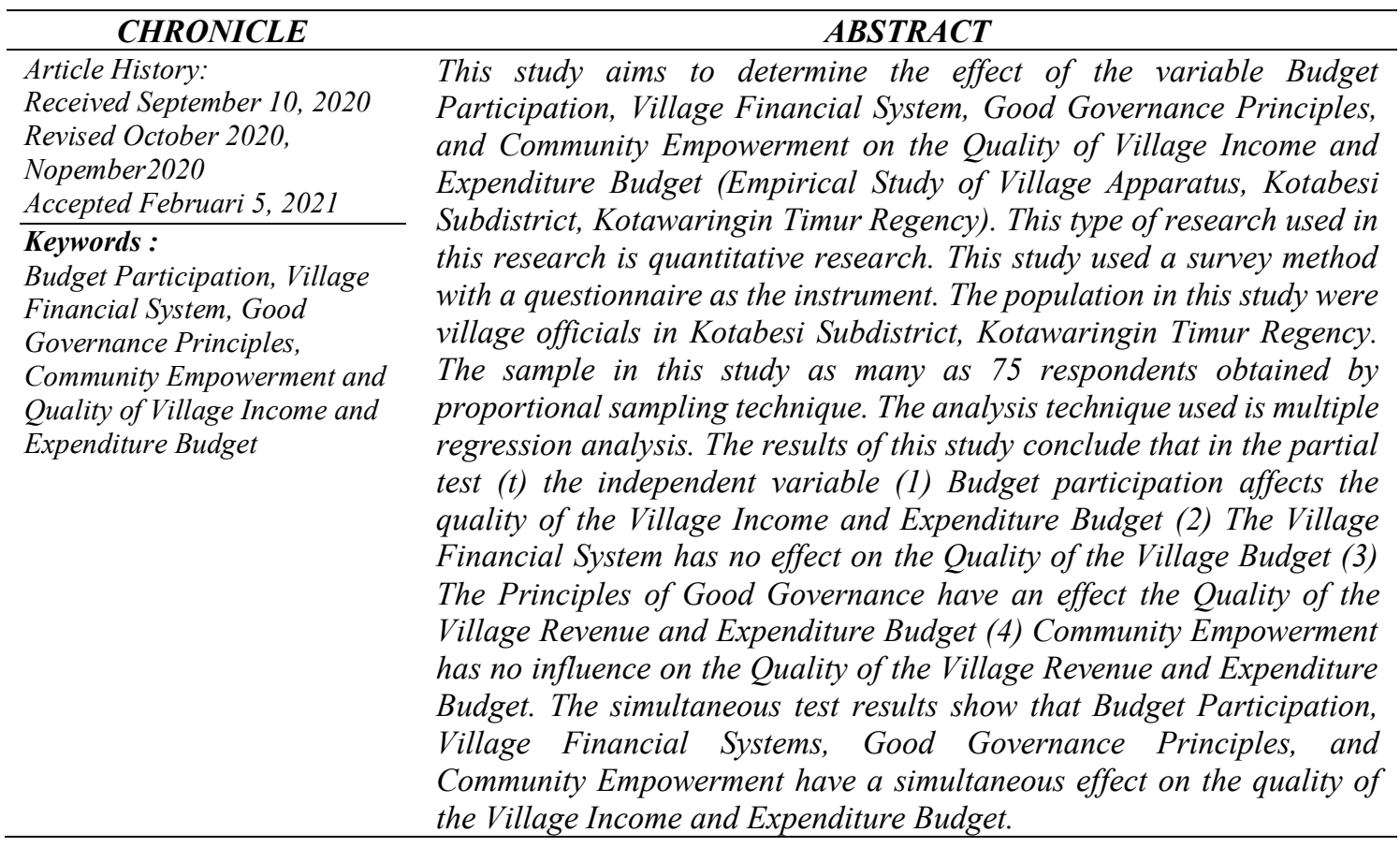

\section{Latar Belakang}

Anggaran Pendapatan dan Belanja Desa adalah suatu daftar terperinci mengenai penerimaan desa yang ditetapkan dalam jangka waktu tertentu biasanya satu tahun sekali.Anggaran Pendapatan dan Belanja Desa merupakan anggaran pemerintah yang diwujudkan dalam bentuk angka yang pada hakikatnya merupakan instrument kebijakan publik sebagai upaya meningkatkan pelayanan kepada masyarakat demi tercapainya pemerintahan yang baik [1]. Anggaran dapat di interetasikan sebagai paket pernyataan menyangkut perkiraan penerimaan dan engeluaran yang di harapkan akan terjadi dalam satu periode mendatang [2]. Anggaran Pendapatan dan Belanja Desa (APBDes) merupakan bagian integral dari perangkat kebijakan pembangunan dan rumah tangga desa, dalam mendukung pelaksanaan pembangunan di desa diperlukan kepastian biaya yang berasal dari berbagai sumber baik pemerintah, swasta maupun masyarakat setempat [3-5].

Penyusunan APBDes didasarkan pada Permendagri No. 37 Tahun 2007 yang merupakan tahap perencanaan keuangan desa. Pengelolaan APBDes didasarkan pada prinsip partisipasi, transparansi, dan akuntabel. Selain mengajarkan pemerintah lebih mandiri dalam mengelola wilayahnya, APBDes juga dapat menjadi saran masyarakat desa untuk menyalurkan aspirasinya dan berpartisipasi dalam pembangunan desa melalui pengelolaan keuangannya. Pengawasan APBDes mengacu pada tindakan atau kegiatan yang dilakukan oleh BPD untuk mengawasi kinerja pemerintah desa.

Tahapan awal dalam membuat rencana-rencana kerja atau kegiatan diawali dengan penyusunan anggaran. Dasar penyusunan anggaran pada rencana kegiatan jangka panjang yang ditetapkan dalam penyusunan program yang perlu dipertimbangkan dan melibatkan manajer dalam penyiapan anggaran dan besarnya pengaruh manajer terhadap bugdeg goals unit organisasi 
yang menjadi tanggungjawab [3,4]. Dalam hal sistem keuangan desa pemerintah desa wajib menyusun Laporan Realisasi Pelaksanaan APBDes. Laporan ini dihasilkandari suatu siklus pengelolaan keuangan desa, yang dimulai dari tahapan perencanaan, pelaksanaan, dan penatausahaan hingga pelaporan, pengawasan dan pertanggungjawaban pengelolaan keuangan desa.

Seiring dengan berkembangnya ke arah demokratis, berkembang pula kebijakan Good Governance. Good Governance merupakan suatu konsep yang mengacu pada proses pencapaian keputusan dan pelaksanaannya dapat dipertanggungjawabkan secara bersama [4]. Penerapan prinsip-prinsip good governance pada dasarnya merupakan perwujudan keamanahan pengelola dalam menjalankan tugas yang diamanahi kepadanya dan kejujuran dalam mengelola keuangan desa [5] . Serta dalam pemahaman mengelola APBDes agar lebih baik karena pada kenyataanya banyak keluhan masyarakat yang berkaitan dengan pengalokasian anggaran yang tidak sesuai dengan kebutuhan prioritas dan kurang efisiensi [6].

Penelitian mengenai APBDes di Indonesia telah dilakukan oleh beberapa peneliti. Berdasarkan peneliti terdahulu, [7] menunjukan bahwa partisipasi anggaran berpengaruh signifikan terhadap peresepsi masyarakat tentang kualitas anggaran pendapatan dan belanja desa. Penerapan sistem keuangan desa berpengaruh signifikan [8,9]. Penelitian ini dilakukan di Kecamatan Kotabesi Kabupaten Kotawaringin Timur. Dilihat dari fenomena yang terjadi di kecamatan kotabesi ada beberapa desa yang masih kurang efisiensi dalam pengelolaan kualitas APBDes, dibeberapa desa infrastruktur fisik belum memadai seperti jalan yang masih belum diaspal dan masih tanah merah struktur tanah yang masih rawa sehingga belum memenuhi standar tanah uruk selain itu seperti penghubung jalan yaitu jembatan yang belum dibangun dan juga ada beberapa desa yang masih belum mempunyai aliran listrik (Sumber: Bernadus, Kaur Pembangunan). Penelitian ini mengambil 9 desa yang ada dikotabesi dan objek penelitian ini berfokus pada aparatur desa. Penelitian ini memfokuskan pada Kualitas Anggaran Pendapatan dan Belanja Desa yang dilakukan oleh pemerintah desa dalam mengelola Anggaran Pendapatan dan Belanja Desa (APBDes) yang juga di pengaruhi oleh beberapa hal yaitu seperti Partisipasi Anggaran, Sistem Keuangan Desa, Prinsip-Prinsip Good Governance, dan Pemberdayaan Masyarakat. Hal ini penting dilakukan agar hasil penelitian dapat dijadikan sebagai evaluasi bagi pemerintah desa Kecamatan Kotabesi dalam mengelola Anggaran Pendapatan dan Belanja Desa.

\section{Tinjauan Pustaka}

\subsection{Kualitas Anggaran Pendapatan dan Belanja Desa}

Anggaran merupakan suatu rencana yang disusun secara sistematis yang meliputi seluruh kegiatan yang dinyatakan dalam unit kesatuan moneter yang berlaku untuk jangka waktu periode yang akan dating [2,9]. Anggaran adalah rencana kegiatan yang akan dijalankan oleh manajemen dalam satu periode yang tertuang secara kuatitatif [10]. Oleh karena itu anggaran menjadi sarana penting dalam hal pengendalian dan perencanaan pada suatu organisasi.

Anggaran merupakan suatu estimasi kinerja yang akan dicapai selama satu periode waktu tertentu dalam ukuran financial. Sedangkan Anggaran Pendapatan dan Belanja Desa (APBDes) dapat di definisikan sebagai rencana operasional keuangan pemerintah daerah, dimana ada satu pihak menggambarkan perkiraan pengeluaran yang setinggi-tingginya guna membiayai kegiatan atau proyek daerah selama satu tahun anggaran tertentu dan pihak lain menggambarkan perkiraan sumber penerimaan daerah guna menutupi pengeluaran-pengeluaran tersebut.

Kualitas anggaran pendapatan dan belanja desa merupakan proses penyusunan, penetapan, pelaksanaan, dan pertanggungjawaban anggaran pendapatan dan belanja desa yang mengkedepankan pemenuhan prinsip keadilan, partisipasi, ekonomis, berbasis kinerja, akuntabilitas, dan disiplin anggaran serta menetukan skala prioritas dan operasional pembangunan yang harus dilakukan untuk mencapai tujuan dan sasaran yang telah ditetapkan $[3,5-10]$.

Struktur anggaran pendapatan belanja desa (APBDes) [11], terdiri atas:

1. Pendapatan

Terdiri dari pendapatan asli daerah (PAD), dana perimbangan, dan lain-lain pendapatan 
daerah yang sah. Pendapatan diakui saat diterima pada rekening kas umum daerah atau oleh entitas pelaporan. Sedangkan pengertian pendapatan daerah berdaskan basis akrual adalah hak pemerintah yang di akui sebagai penambahan nilai kekayaan bersih, kekayaan diakui saat timbulnya hak atas pendapatan tersebut.

2. Belanja

Belanja terdiri dari belanja aparatur daerah, belanja pelayanan publik, belanja bagi hasil dan bantuan keuangan, belanja tak terduga. Belanja diakui saat terjadinya pengeluarah dari rekening umum daerah atau entitas. Khusus pengeluaran melalui bendahara pengakuannya terjadi saat pertanggungjawaban atas pengeluaran tersebut di sahkan oleh unit yang mempunyai fungsi perbendaharaan.

3. Pembiayaan

Terdiri dari penerimaan daerah dan pengeluaran daerah. Penerimaan pembiaayan adalah semua penerimaan yang terdapat pada rekening kas umum daerah. Penerimaan pembiayaan dikelompokkan meliputi sisa lebih perhitungan anggaran tahun lalu seperti penerimaan PAD, penerimaan dana perimbangan, pencairan dana cadangan, penerimaan pinjaman daerah dan penerimaan piutang daerah.

Setelah diadakan rancangan anggaran belanja maka tiap tahun sebelum tutup tahun di adakan rapat desa dimana rancangan anggaran belanja buat tahun depannya yang telah di siapkan oleh lurah dengan bantuan dan di bawah pimpinan camat di bicarakan dan ditetapkan. Pengelolaan keuangan dilaksanakan oleh bendaharawan desa yang diangkat oleh kepala desa setelah mendapat persetujuan dari Badan Perwakilan Desa (BPD), pengelolaan APBDes tersebut dipertanggungjawabkan oleh kepala desa kepada Badan Perwakilan Desa selambat-lambatnya tiga bulan setelah berakhir tahun anggaran.

\subsection{Prinsip-Prinsip Good Governance}

Good governance merupakan suatu konsep yang mengacu kepada proses pencapaian keputusan dan pelaksanaan yang dapat dipertanggungjawabkan secara bersama. Good governance merupakan penyelengaraan manajemen pembangunan yang bertanggungjawab sejalan dengan prinsip demokrasi yang bertujuan untuk menghindari adanya salah alokasi dana investasi dan pencegahan korupsi baik secara politik maupun administrative [4,7-10]. Prinsipprinsip good governance merupakan prinsip yang melandasi tata pemerintahan yang baik dan menjadi pedoman dalam penyelenggaran pemerintahan daerah yang berfokus untuk pertumbuhan sektor publik serta bersinergi untuk mengelola sumber daya yang dimiliki suatu daerah dengan tata kelola pemerintahan yang baik secara efektif dan efisien untuk kepentingan masyarakat sehingga terwujudnya tata kelola pemerintahan desa yang baik $[9,12]$.

Dalam penerapan Good Governance perlu diperhatikan prinsip-prinsip dasar yang telah menjadi pedoman dalam penyelenggaran pemerintahan daerah. Secara umum prinsip-prinsip dasar good governance menurut Organization for Econimic Coorperation and Development dalam $[4,10,12]$ menyebutkan terdapat 4 hal pokok yang menjadi prinsip dasar good governance antara lain keadilan, transparansi, akuntabilitas, dan responsibilitas. Namun apabila diperdalam lagi maka prinsip good governance memiliki 9 prinsip yaitu Partisipasi Masyarakat, Tegaknya Supremasi Hukum, Peduli Kepada Masyarakat, Berorientasi Pada Konsensus, Efektif dan Efisien, Keadilan, Transparansi, Tanggungjawab, Akuntabilitas.

\subsection{Pemberdayaan Masyarakat}

Pengertian pemberdayaan masyarakat menurut Kamus Besar Bahasa Indonesia (KBBI) adalah proses, cara, membuat, memberdayakan dari kata daya yaitu kemampuan melakukan sesuatu atau kemampuan untuk bertindak. Pemberdayaan merupakan suatu cara rakyat, organisasi dan komitmen diarahkan agar mampu menguasai kehidupan atau pemberdayaan di anggap sebuah proses menjadikan orang yang cukup kuat untuk berpartisipasi terhadap kejadiankejadian serta lembaga yang mempengaruhi kehidupannya [13-16]. 
IEMBA: Jurnal Ekonomi Pembangunan, Manajemen dan Bisnis, Akuntansi

Volume 1. No. 1 (Maret 2021) / e-journal.upr.ac.id

Pemberdayaan masyarakat terutama di pedesaan tidak cukup hanya dengan upaya meningkatkan produktivitas, memberikan kesempatan usaha yang sama atau memberikan modal saja, tetapi masyarakat harus di ikuti pula dengan perubahan struktur sosial ekonomi masyarakat, mendukung berkembangnya potensi masyarakat melalui peningkatan peran, produktivitas dan efisiensi serta memberikan empat akses yaitu:

1. Akses terhadap sumber daya.

2. Akses terhadap teknologi.

3. Akses terhadap pasar.

4. Akses terhadap sumber pembiayaan.

Keempat akses ini menjadi tanggungjawab pemerintah untuk memfasilitasinya, juga diperlukan peran aktif dari kelompok-kelompok masyarakat di desa dan kelurahan untuk membentuk usaha bersama atau kepentingan bersama yang diselenggarakan secara kekeluargaan. Pemberdayaan menekankan bahwa orang memperoleh keterampilan, pengetahuan, dan kekuasaan yang cukup untuk mempengaruhi kehidupannya dan kehidupan orang lain yang menjadi perhatian.

Dalam pemberdayaan masyarakat dibutuhkan tahap pemberdayaan yang jelas dan terarah, disebutkan tahap-tahap pemberdayaan masyarakat ada beberapa yang harus dilakukan antara lain:

1. Meningkatkan kesadaran kritis atau posisi masyarakat dalam struktur sosial politik. Hal ini berangkat dari asumsi bahwa sumber kemiskinan berasal dari konstruksi sosial yang ada pada masyarkat itu sendiri.

2. Kesadaran kritis yang muncul diharapkan membuat masyarakat mampu membuat argumen terhadap berbagai macam eksploitasi serta sekaligus membuat pemutusan terhadap segala hal.

3. Peningkatan kapasitas masyarakat dalam hal ini perlu dipahami bahwa masalah kemiskinan bukan sekedar persoalan kesejahtraan sosial tetapi berkaitan dengan faktor politik, ekonomi, sosial budaya dan keamanan.

4. Pemberdayaan juga perlu meningkatkan dengan pembangunan sosial budaya masyarakat.

Berdasarkan teori di atas maka disusunlah kerangka penelitian sebagai berikut:

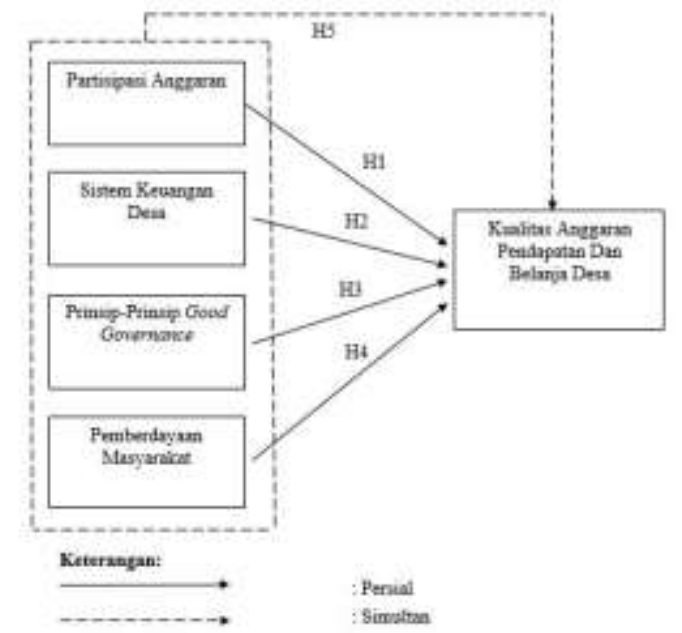

Gambar 1. Kerangka penelitian (sumber : diolah penulis)

\section{Metode Penelitian}

Desain penelitian yang digunakan adalah deskriptif kuantitatif yang menekankan pada pengujian teori melalui pengukuran variabel dengan angka dan melakukan analisis data menggunakan prosedur statistik dengan bantuan program SPSS 24. Data yang digunakan dalam 
IEMBA: Jurnal Ekonomi Pembangunan, Manajemen dan Bisnis, Akuntansi

Volume 1. No. 1 (Maret 2021) / e-journal.upr.ac.id

penelitian ini adalah data primer yaitu data yang diperoleh secara langsung dari sumber utama seperti responden atau subjek penelitian melalui kuesioner, wawancara, survei, dan dokumentasi [9-11,18]. Populasi penelitian ini adalah aparatur desa di Kecamatan Kotabesi Kabupaten Kotawaringin Timur. Dengan populasi sebanyak 99 aparatur desa untuk pengisian angket. Sampel yang digunakan pada penelitian ini sebanyak 80 orang yang dihitung dengan menggunakan rumus Slovin yang diantaranya adalah Kepala Desa, Sekretaris Desa, Kaur Pembangunan, Kaur Keuangan, Kaur Umum, Kasi Kesejahtraan, Operator Siskeudes, BPD dan Ketua RT.

Pengujian secara statistic akan dilakukan mulai dari pengujian validitas, reliabilitas, normalitas, dan uji regresi berganda. Persamaan regresi dalam penelitian ini adalah untuk mengetahui seberapa besar pengaruh variabel independen yaitu Partisipasi Anggaran (X1), Sistem Keuangan Desa (X2), Prinsip-Prinsip Good Governance (X3), Pemberdayaan Masyarakat (X4), terhadap Kualitas Anggaran Pendapatan dan Belanja Desa (Y).

Rumusan matematis dari regresi berganda yang digunakan dalam penelitian ini adalah:

$$
\mathrm{Y}=\mathrm{a}+\mathrm{b}_{1} \mathrm{X}_{1}+\mathrm{b}_{2} \mathrm{X}_{2}+\mathrm{b}_{3} \mathrm{X}_{3}+\mathrm{b}_{4} \mathrm{X}_{4}+e
$$

Keterangan:

$\mathrm{Y} \quad=$ Kualitas Anggaran Pendapatan dan Belanja Desa

a $=$ constanta

b1 = koefisien regresi antara partisipasi anggaran terhadap kualitas anggaran pendapatan dan belanja desa

b2 = koefisien regresi antara sistem keuangan desa terhadap kualitas anggaran pendapatan dan belanja desa

b3 = koefisien regresi antara prinsip-prinsip good govenance terhadap kualitas anggaran pendapatan dan belanja desa

b4 = koefisien regresi antara pemberdayaan masyarakat terhadap kualitas anggaran pendapatan dan belanja desa

$\mathrm{X} 1=$ variabel partisipasi anggaran

$\mathrm{X} 2=$ variabel sistem keuangan desa

$\mathrm{X} 3=$ variabel prinsip-prinsip good governance

$\mathrm{X} 4$ = variabel pemberdayaan masyarakat

$\mathrm{e} \quad=$ error disturbance

Selanjutnya hipotesis akan diuji dengan uji $t$ dan uji F. Uji t adalah untuk mengetahui seberapa jauh pengaruh dari variabel independen terhadap variabel dependen secara persial. Pengajuan hipotesis akan dilakukan dengan menggunakan tingkat signifikan sebesar $0,05(\alpha=5 \%)$ atau tingkat keyakinan sebesar 0,95 . Uji $\mathrm{F}$ pada dasarnya menunjukan apakah semua variabel independen atau variabel bebas yang dimasukan dalam model mempunyai pengaruh secara bersama-sama terhadap variabel dependen atau variabel terikat

\section{Hasil Penelitian}

\subsection{Uji Pendahuluan}

Dalam uji pendahuluan ini dilakukan uji validitas, reliabilitas, dan normalitas. Hasil uji validitas mentakan bahwa semua item pertanyaan yang diberikan adalah valid $[6,18]$. Uji validitas dilakukan untuk mengetahui kelayakan butir-butir dalam suatu pertanyaan untuk mendefinisikan suatu variabel. Sebuah instrumen pengukuran dikatakan valid apabila instrumen tersebut mengukur hal yang seharusnya diukur [8]. Sementara dari pengujian reliabilitas juga menyatakan bahwa semua item reliabel yang berarti bahwa jawaban dari responden terhadap pertanyaan adalah konsisten dari waktu ke waktu. Dari hasil uji normalitas menunjukan bahwa hasil uji normalitas dengan Kolmogorov -Smirnov test menunjukan Asymp.Sig lebih besar dari pada 0,05 untuk setiap variabel maka dapat dikatakan data berdistribusi normal. 
IEMBA: Jurnal Ekonomi Pembangunan, Manajemen dan Bisnis, Akuntansi Volume 1. No. 1 (Maret 2021) / e-journal.upr.ac.id

\subsection{Analisis Linier Berganda}

Analisis regresi linear berganda digunakan untuk melihat hubungan antara satu atau beberapa variabel independen dengan sebuah variabel dependen. Persamaan regresi dalam penelitian ini adalah untuk mengetahui seberapa besar pengaruh variabel independen yaitu Partisipasi Anggaran (X1), Sistem Keuangan Desa (X2), Prinsip-Prinsip Good Governance (X3), Pemberdayaan Masyarakat (X4), terhadap Kualitas Anggaran Pendapatan dan Belanja Desa (Y). Pengujian hipotesisi pada penelitian ini menggunakan regresi linear berganda dengan bantuan SPSS 24.

Hasil dari analisis linear berganda dalam penelitian ini dapat dilihat pada tabel 1:

Tabel 1. Hasil Analisis Regresi Linear Berganda

\begin{tabular}{|c|c|c|c|c|c|c|}
\hline & \multirow{2}{*}{ Model } & \multicolumn{2}{|c|}{$\begin{array}{l}\text { Unstandardized } \\
\text { Coefficients }\end{array}$} & \multirow{2}{*}{$\begin{array}{c}\text { Standardized } \\
\text { Coefficients }\end{array}$} & \multirow[t]{2}{*}{$\mathrm{t}$} & \multirow[t]{2}{*}{ Sig. } \\
\hline & & B & $\begin{array}{l}\text { Std. } \\
\text { Error }\end{array}$ & & & \\
\hline \multirow[t]{5}{*}{1} & (Constant) & .809 & .323 & & 2.503 & .015 \\
\hline & Partisipasi anggaran & .217 & .083 & .242 & 2.622 & .011 \\
\hline & Sistem keuangan desa & .068 & .096 & .085 & .715 & .477 \\
\hline & $\begin{array}{l}\text { Prinsip-prinsip good } \\
\text { governance }\end{array}$ & .462 & .094 & .533 & 4.897 & .000 \\
\hline & $\begin{array}{l}\text { Pemberdayaan } \\
\text { masyarakat }\end{array}$ & .046 & .102 & .055 & 456 & .650 \\
\hline
\end{tabular}

Sumber : Data diolah

Berdasarkan dari hasil regresi linear berganda yang di dapat maka dapat dibuat persamaan sebagai berikut:

$\mathrm{Y}=0,809+0,217+0,068+0,462+0,046+\mathrm{e}$

Persamaan regresi berganda diatas dapat diartikan bahwa:

a. Nilai konstanta $(\alpha)$ sebesar 0,809 yang berarti bahwa jika tidak ada variabel bebas lain yang terdiri dari partisipasi anggaran, sistem keuangan desa, prinsip-prinsip good governance, dan pemberdayaan masyarakat yang memengaruhi kualitas anggaran pendapatan dan belanja desa maka besarnya peningkatan kualitas anggaran pendapatan dan belanja desa di Kecamatan Kotabesi adalah 0,809

b. Koefisien regresi variabel partisipasi anggaran 0,217. Ini menunjukan bahwa setiap terjadi kenaikan partisipasi anggaran maka akan meningkatkan kualitas anggaran pendapatan dan belanja desa sebesar 0,217 atau sebesar $21,7 \%$ tanpa dipengaruhi faktor lain.

c. Koefisien regresi variabel sistem keuangan desa 0,068 . Ini menunjukan bahwa setiap terjadi kenaikan sistem keuangan desa maka akan meningkatkan kualitas anggaran pendapatan dan belanja desa sebesar 0,068 atau sebesar $06,8 \%$ tanpa dipengaruhi faktor lain.

d. Koefisien regresi variabel prinsip-prinsip good governance 0,462. Ini menunjukan bahwa setiap terjadi kenaikan prinsip-prinsip good governance maka akan meningkatkan kualitas anggaran pendapatan dan belanja desa sebesar 0,462 atau sebesar 46,2\% tanpa dipengaruhi faktor lain.

e. Koefisien regresi variabel pemberdayaan masyarakat 0,046. Ini menunjukan bahwa setiap terjadi kenaikan pemberdayaan masyarakat maka akan meningkatkan kualitas anggaran pendapatan dan belanja desa sebesar 0,046 atau sebesar 04,6\% tanpa dipengaruhi faktor lain. 
IEMBA: Jurnal Ekonomi Pembangunan, Manajemen dan Bisnis, Akuntansi

Volume 1. No. 1 (Maret 2021) / e-journal.upr.ac.id

\subsection{Uji Parsial (Uji t)}

Uji t digunakan untuk mempengaruhi masing-masing variabel independen terhadap dependen. Hipotesis diterima apabila nilai sig lebih kecil 0,05 atau thitung lebih besar dari $\mathrm{t}$ tabel maka terdapat pengaruh variabel $\mathrm{X}$ terhadap $\mathrm{Y}$ sebaliknya jika nilai sig lebih besar dari 0,05 atau thitung lebih kecil dari $t$ tabel maka tidak terdapat pengaruh variabel $\mathrm{X}$ terhadap $\mathrm{Y}$. Hasil uji t dalam penelitian ini dapat dilihat sebagai berikut:

Tabel 2. Hasil Uji t

\begin{tabular}{|l|c|c|c|c|}
\hline \multicolumn{1}{|c|}{ Variabel } & $\mathrm{T}$ & Sig & $\begin{array}{c}\mathrm{T} \text { tabel } \\
5 \%\end{array}$ & Keterangan \\
\hline Partisipasi Anggaran & 2.622 & .011 & 1.994 & Berpengaruh \\
\hline Sistem Keuangan Desa & .715 & .477 & 1.994 & Tidak Berpengaruh \\
\hline $\begin{array}{l}\text { Prinsip-Prinsip Good } \\
\text { Governance }\end{array}$ & 4.897 & .000 & 1.994 & Berpengaruh \\
\hline $\begin{array}{l}\text { Pemberdayaan } \\
\text { Masyarakat }\end{array}$ & .456 & .650 & 1.994 & Tidak Berpengaruh \\
\hline
\end{tabular}

Sumber : Data penelitian diolah, 2020

Berdasarkan tabel 2 hasil uji parsial maka dapat diketahui pengaruh masing-masing variabel sebagai berikut:

a. Hasil Pengujian Pengaruh Partisipasi Anggaran Terhadap Kualitas Anggaran Pendapatan dan Belanja Desa menyatakan bahwa sehingga partisipasi anggaran secara parsial berpengaruh terhadap kualitas anggaran pendapatan dan belanja desa.

b. Hasil Pengujian Pengaruh Sistem Keuangan Desa Terhadap Kualitas Anggaran Pendapatan dan Belanja Desa menyatakan bahwa sistem keuangan desa secara parsial tidak berpengaruh terhadap kualitas anggaran pendapatan dan belanja desa.

c. Hasil Pengujian Prinsip-Prinsp Good Governance Terhadap Kualitas Anggaran Pendapatan dan Belanja Desa menyatakan bahwa prinsip-prinsip good governance secara parsial berpengaruh terhadap kualitas anggaran pendapatan dan belanja desa.

d. Hasil Pengujian Pemberdayaan Masyarakat Terhadap Kualiatas Anggaran Pendapatan dan Belanja Desa menyatakan bahwa pemberdayaan masyarakat secara parsial tidak berpengaruh terhadap kualitas anggaran pendapatan dan belanja desa.

Analisis linier berganda digunakan untuk mengetahui pengaruh kinerja lingkungan (PROPER), profitabilitas (ROA), ukuran perusahaan (SIZE) dan Kepemilikan saham public (KSP) terhadap pengungkapan CSR. Hasil dari analisis tersebut disajikan pada tabel berikut:

Tabel 1. Uji Regresi Linier Berganda

\begin{tabular}{|c|c|c|c|c|c|c|}
\hline & \multirow{2}{*}{ Model } & \multicolumn{2}{|c|}{$\begin{array}{c}\text { Unstandardized } \\
\text { Coefficients }\end{array}$} & \multirow{2}{*}{$\begin{array}{c}\begin{array}{c}\text { Standardized } \\
\text { Coefficients }\end{array} \\
\text { Beta }\end{array}$} & \multirow[t]{2}{*}{$\mathrm{T}$} & \multirow[t]{2}{*}{ Sig. } \\
\hline & & B & $\begin{array}{l}\text { Std. } \\
\text { Error }\end{array}$ & & & \\
\hline \multirow[t]{5}{*}{1} & (Constant) & 1,381 & , 184 & & 7,492 & ,000 \\
\hline & PROPER &, 095 &, 030 & ,287 & 3,141 &, 012 \\
\hline & ROA & ,159 & ,163 & ,092 & ,973 & ,333 \\
\hline & SIZE &, 025 & ,006 & ,389 & 4,037 &, 032 \\
\hline & KSP & ,002 & ,001 &, 144 & 1,582 &, 017 \\
\hline
\end{tabular}

Sumber: Data diolah, 2020 
IEMBA: Jurnal Ekonomi Pembangunan, Manajemen dan Bisnis, Akuntansi

Volume 1. No. 1 (Maret 2021) / e-journal.upr.ac.id

Berdasarkan hasil analisis regresi linear berganda pada Tabel 1 diatas maka persamaan regresinya adalah sebagai berikut:

$\mathrm{CSR}=1,381+0,095 \mathrm{PROPER}+0,159 \mathrm{ROA}+0,025 \mathrm{SIZE}+0,002 \mathrm{KSP}+0,184$

Persamaan regresi pertama di atas dapat diartikan sebagai berikut:

1. Konstanta $(\alpha)$ sebesar 1,381 artinya jika kinerja lingkungan (PROPER) bernilai 0 , maka CSR adalah bernilai sebesar 1381 .

2. Nilai koefisien regresi dari kinerja lingkungan (PROPER) adalah 0,095 artinya jika PROPER mengalami kenaikan, maka CSR mengalami kenaikan sebesar 0,095. Koefisien bernilai positif artinya terjadi hubungan positif antara kinerja lingkungan terhadap pengungk apan Corporate Social Responsibility.

3. Nilai koefisien regresi dari kinerja perusahaan (ROA) adalah 0,159 artinya jika ROA mengalami kenaikan, maka CSR mengalami kenaikan sebesar 0,159 . Koefisien bernilai positif artinya terjadi hubungan positif antara kinerja perusahaan terhadap pengungkapan Corporate Social Responsibility.

4. Nilai koefisien regresi dari ukuran perusahaan (SIZE) adalah 0,025 artinya jika SIZE mengalami kenaikan, maka CSR mengalami kenaikan sebesar 0,025 . Koefisien bernilai positif artinya terjadi hubungan positif antara SIZE terhadap pengungkapan Corporate Social Responsibility.

5. Nilai koefisien regresi dari kepemilikan saham publik adalah 0,002 artinya jika kepemilikan saham publik mengalami kenaikan, maka CSR mengalami kenaikan sebesar 0,002. Koefisien bernilai positif artinya terjadi hubungan positif antara kepemilikan saham publik terhadap pengungkapan Corporate Social Responsibility.

\subsection{Uji Parsial (uji-t)}

Uji parsial (uji-t) bertujuan untuk mengetahui sacara individual pengaruh satu variabel independen terhadap variabel dependen. Derajat signifikansi yang digunakan adalah 0,05. Apabila nilai signifikansi lebih kecil dari derajat kepercayaan maka hipotesis alternatif dapat diterima yang berarti suatu variabel independen secara parsial mempengaruhi variabel dependen. Hasil uji t dapat dilihat pada tabel berikut:

Tabel 2. Hasil Uji Parsial (uji-t)

\begin{tabular}{|c|c|c|c|c|c|c|}
\hline & M 1 & $\begin{array}{r}\text { Unstan } \\
\text { Coef }\end{array}$ & $\begin{array}{l}\text { dized } \\
\text { ents }\end{array}$ & $\begin{array}{l}\text { Standardized } \\
\text { Coefficients }\end{array}$ & $T$ & S: \\
\hline & & B & $\begin{array}{l}\text { Std. } \\
\text { Error }\end{array}$ & Beta & & \\
\hline 1 & (Constant) & 1,381 & ,184 & & 7,492 &, 000 \\
\hline & PROPER & ,095 &, 030 & ,287 & 3,141 & ,012 \\
\hline & ROA & ,159 & ,163 & ,092 & ,973 & ,333 \\
\hline & SIZE &, 025 &, 006 & ,389 & 4,037 &, 032 \\
\hline & KSP & ,002 & 001 &, 144 & 1,582 & 017 \\
\hline
\end{tabular}

Sumber: Data diolah, 2020

Berdasarkan Tabel 2 di atas maka hasil pengujian hipotesis masing-masing variabel independen secara parsial terhadap variabel dependennya. Jadi interpretasinya untuk uji t dalam penelitian ini sebagai berikut:

1. Kinerja lingkungan (PROPER) memiliki pengaruh terhadap pengungkapan CSR. Ini ditunjukkan dengan nilai signifikansi $0,012<0,05$. Nilai T hitung adalah 3,141 sedangkan 
JEMBA: Jurnal Ekonomi Pembangunan, Manajemen dan Bisnis, Akuntansi

Volume 1. No. 1 (Maret 2021) / e-journal.upr.ac.id

nilai $\mathrm{T}$ tabel 1,985, yang berarti bahwa $\mathrm{T}$ hitung $>\mathrm{T}$ tabel, sehingga hipotesis $\mathrm{X} 1$ diterima.

2. Profitabilitas (ROA) tidak memiliki pengaruh terhadap pengungkapan CSR. Ini ditunjukkan dengan besarnya nilai signifikansi $0,333>0,05$. Nilai T hitung adalah 0,973 sedangkan nilai $\mathrm{T}$ tabel 1,985, yang berarti bahwa $\mathrm{T}$ hitung $<\mathrm{T}$ tabel, sehingga hipotesis $\mathrm{X} 2$ ditolak.

3. Ukuran perusahaan (SIZE) memiliki pengaruh terhadap pengungkapan CSR. Ini ditunjukkan dengan nilai signifikansi $0,032<0,05$. Nilai $\mathrm{T}$ hitung adalah 4,037 sedangkan nilai $\mathrm{T}$ tabel 1,985, yang berarti bahwa T hitung $>\mathrm{T}$ tabel, sehingga hipotesis $\mathrm{X} 3$ dapat diterima,

4. Kepemilikan saham publik memiliki pengaruh terhadap pengungkapan CSR. Ini ditunjukkan dengan nilai signifikansi $0,017<0,05$. Nilai $\mathrm{T}$ hitung adalah 1,582 sedangkan nilai $\mathrm{T}$ tabel 1,985 , yang berarti bahwa $\mathrm{T}$ hitung $<\mathrm{T}$ tabel, sehingga hipotesis diterima.

\subsection{Uji Simultan (uji-F)}

Uji F pada dasarnya menunjukan apakah semua variabel independen atau variabel bebas yang dimasukan dalam model mempunyai pengaruh secara bersama-sama terhadap variabel dependen atau variabel terikat. Berikut hasil pengujian simultan variabel X terhadap $\mathrm{Y}$ dengan bantuan SPSS 24 dapat dilihat di tabel 3 :

Tabel 3. Hasil Uji Simultan (uji-F)

\begin{tabular}{|l|l|c|c|}
\hline \multicolumn{2}{|l|}{ Model } & F & Sig \\
\hline \multirow{2}{*}{1} & Regression & 31.132 & $.000^{\mathrm{b}}$ \\
\cline { 2 - 4 } & Residual & 17.033 & - \\
\hline
\end{tabular}

Sumber : Data diolah, 2020

Berdasarkan Tabel 3 diperoleh nilai signifikansi pada uji $\mathrm{F}$ sebesar 0,041. Nilai signifikansi tersebut lebih kecil dari 0,05 . Nilai $F$ hitung 7.806 dan nilai $F$ tabel adalah 2,47 nilai $F$ hitung $>$ F tabel. Sehingga dapat disimpulkan bahwa ada pengaruh secara simultan antara variabel independen yaitu kinerja lingkungan (PROPER), profitabilitas (ROA), ukuran perusahaan (SIZE) dan kepemilikan saham publik (KSP) terhadap pengungkapan CSR.

\subsection{Koefesien Determinasi (Adjusted $R^{2}$ )}

Koefisien diterminasi bertujuan untuk mengukur seberapa jauh kemampuan model dalam menerangkan variasi variabel dependen $[3,9,17]$. Nilai koefisien diterminasi yang mendekati Koefisien determinasi yang mendekati atau berarti variabel independen memberikan hampir semua informasi yang dibutuhkan untuk memprediksi variabel dependen. Hasil pengujian diterminasi ditunjukan pada tabel 4 berikut:

Tabel 4. Koefesien Determinasi

\begin{tabular}{|l|r|r|r|r|}
\hline Model & \multicolumn{1}{|c|}{$\mathrm{R}$} & R Square & $\begin{array}{c}\text { Adjusted R } \\
\text { Square }\end{array}$ & $\begin{array}{c}\text { Std. Error of } \\
\text { the Estimate }\end{array}$ \\
\hline 1 & $.800^{\mathrm{a}}$ & .640 & .620 & .209 \\
\hline
\end{tabular}

Sumber : Data penelitian diolah, 2020

Nilai adjusted $\mathrm{R}^{2}$ dapat dilihat pada tabel 4.12 yaitu sebesar 0,620 atau $62,0 \%$ nilai tersebut menunjukan bahwa partisispasi anggaran, sistem keuangan desa, prinsip-prinsip good governance, dan pemberdayaan masyarakat memberikan pengaruh $62,0 \%$ terhadap kualitas anggaran pendapatan dan belanja desa, sedangkan sisianya 38,0\% merupakan pengaruh dari variabel bebas lainnya. 
JEMBA: Jurnal Ekonomi Pembangunan, Manajemen dan Bisnis, Akuntansi Volume 1. No. 1 (Maret 2021) / e-journal.upr.ac.id

\section{Kesimpulan}

Berdasarkan hasil penelitian dan pengujian hipotesis yang telah dilakukan, maka hasil penelitian dapat disimpulkan dari hasil pengujian secara parsial menunjukan bahwa partisipasi anggaran memiliki pengaruh yang signifikan terhadap kualitas anggaran pendapatan dan belanja desa. Hal ini berarti dengan adanya partisipasi anggaran masyarakat dapat memberikan saran sehingga dapat menjadi bahan pertimbangan dalam penyusunan APBDes dan menghasilkan kualitas anggaran pendapatan dan belanja desa yang relevan. Sistem keuangan desa memiliki pengaruh yang tidak signifikan terhadap kualitas anggaran pendapatan dan belanja desa. Hal ini berarti dengan adanya sistem keuangan desa laporan yang disajikan tidak konsisten dan tidak meningkatkan mutu pelayanan serta pendapatan desa. Prinsip-prinsip good governance memiliki pengaruh yang signifikan terhadap kualitas anggaran pendapatan dan belanja desa. Hal ini berarti dengan adanya prinsip-prinsip good governance pemerintah desa menyusun program yang berorientasi pada peningkatan kesejahtraan masyarakat sehingga menghasilkan kualitas anggaran pendapatan dan belanja desa yang lebih relevan. Pemberdayaan masyarakat memiliki pengaruh yang tidak signifikan terhadap kualitas anggaran pendapatan dan belanja desa. Hal ini berarti pemberdayaaan masyarakat tidak memberikan pegembangan kualitas hidup masyarakat dan tidak memberikan peningkatan kesejahtraan masyarakat desa. Partisipasi anggaran, sistem keuangan desa, prinsip-prinsip good governance, dan pemberdayaan masyarakat berpengaruh secara simultan terhadap kualitas anggaran pendapatan dan belanja desa. Hal ini menunjukkan partisipasi anggaran, sistem keuangan desa, prinsip-prinsip good governance, dan pemberdayaan masyarakat sesuai dengan program yang disepakati berdasarkan prioritas untuk meningkatkan kemajuan dan infrastruktur desa.

\section{REFERENSI}

[1] Latuheru, B. P. (2012). Pengaruh Partisipasi Anggaran Terhadap Senjangan Anggaran Dengan Komitment Organisasi Sebagai Variabel Moderating (Studi Empiris Pada Kawasan Industri Maluku). Jurnal Akuntansi dan Sistem Teknologi Informasi, 5(1).

[2] Hanifah, S. I., \& Praptoyo, S. (2015). Akuntabilitas dan Transparansi Pertanggungjawaban Anggaran Pendapatan Belanja Desa (APBDes). Jurnal Ilmu \& Riset Akuntansi, 4(8), 1-15.

[3] Mamesah, F. Y. (2014). Peranan Badan Permusyawaratan Desa dalam Penyusunan Anggaran Pendapatan dan Belanja Desa (suatu Studi di Desa Sendangan Kecamatan Tompaso) 1. Politico: Jurnal Ilmu Politik, 2(6), 1054.

[4] Yulianeu, A., \& Tohir, C. (2017). Aplikasi Rancangan Anggaran Pendapatan Belanja Desa Menggunakan Metode Accrual Basic di Desa Sukaratu Kabupaten Tasikmalaya. Jurnal Manajemen Informatika (JUMIKA), 3(2).

[5] Novie, Ahia. "AKUNTABILITAS PENGELOLAAN ANGGARAN PENDAPATAN DAN BELANJA DESA DI DESA TELANGKAH KECAMATAN KATINGAN HILIR KABUPATEN KATINGAN." Wacana: Jurnal Ilmu Sosial dan Ilmu Politik Interdisiplin 5, no. 2 (2018): 65-75.

[6] Sulina, I. G. A. T., Wahyuni, M. A., Kurniawan, P. S., \& ST, M. (2018). Peranan sistem keuangan desa (Siskeudes) terhadap kinerja pemerintah desa (studi kasus di desa Kaba-kaba, Kecamatan Kediri, Kabupaten Tabanan). JIMAT (Jurnal Ilmiah Mahasiswa Akuntansi) Undiksha, 8(2).

[7] Arfiansyah, Mufti Arief. "Pengaruh Sistem Keuangan Desa dan Sistem Pengendalian Intern Pemerintah Terhadap Akuntabilitas Pengelolaan Dana Desa." JIFA (Journal of Islamic Finance and Accounting) 3, no. 1 (2020).

[8] Rivan, A., \& Maksum, I. R. (2019). Penerapan Sistem Keuangan Desa (siskeudes) dalam Pengelolaan Keuangan Desa. Jurnal Administrasi Publik: Public Administration Journal, 9(2), 92-100.

[9] Wiguna, I. M. D. P. D., Yuniarta, G. A., Ak, S. E., \& Prayudi, M. A. (2018). Pengaruh Kualitas Sumber Daya Manusia, Pendidikan Dan Pelatihan, Serta Peran Pendamping Desa Terhadap Efektivitas Penggunaan Sistem Keuangan Desa (Siskeudes)(Studi Pada Desa Penerima Dana Desa Di Kabupaten Buleleng). JIMAT (Jurnal Ilmiah Mahasiswa Akuntansi) Undiksha, 8(2).

[10] Heriyanto, A. (2015). Penerapan Prinsip-Prinsip Good Governance dalam Tata Kelola Pemerintahan Desa Triharjo Kecamatan Sleman Kabupaten Sleman. Universitas PGRI Yogyakarta. 
IEMBA: Jurnal Ekonomi Pembangunan, Manajemen dan Bisnis, Akuntansi

Volume 1. No. 1 (Maret 2021) / e-journal.upr.ac.id

[11] Ningrum, E. A., \& Isril, I. (2016). Studi Penerapan Good Governance dalam Pengelolaan Desa Wisata Kampung Bandar Kecamatan Senapelan Kota Pekanbaru Tahun 2012-2014 (Doctoral dissertation, Riau University).

[12] Faradhiba, L., \& Diana, N. (2018). AKUNTABILITAS PEMERINTAHAN DESA DALAM PENGELOLAAN ANGGARAN PENDAPATAN DAN BELANJA DESA (APBDES)(Studi Kasus di Desa Banjarsari Kecamatan Bandarkedungmulyo-Jombang). Jurnal Ilmiah Riset Akuntansi, 7(07).

[13] Mangindaan, J. V., \& Manossoh, H. (2019). Kualitas Sumber Daya Manusia Pemerintah Desa Dalam Pengelolaan Dana Desa Yang Bersumber Dari Anggaran Pendapatan Dan Belanja Negara Di Kecamatan Tabukan Utara Kab. Kepulauan Sangihe. Jurnal LPPM Bidang Ekososbudkum, 4(1), $35-$ 49.

[14] Puspasari, O. R., \& Purnama, D. (2018). Implementasi sistem keuangan desa dan kualitas laporan keuangan pemerintah desa di kabupaten kuningan. Jurnal Kajian Akuntansi, 2(2), 145-159.

[15] Ahyaruddin, M., \& Ramadanis, R. (2019). Akuntabilitas dan Transparansi Pengelolaan Anggaran Pendapatan dan Belanja Desa (APBDes). Jurnal Akuntansi Dan Ekonomika, 9(1), 110-118.

[16] Tyas, D. W. (2018). Kinerja Aparatur Desa dalam Penyusunan Anggaran Pendapatan dan Belanja Desa di Desa Siringan-ringan Kecamatan Ujung Padang Kabupaten Simalungun.

[17] Lestari, K. A. D., Trisnadewi, A. E., \& Jayanti, L. S. E. (2020). Analisis Efektivitas Pengelolaan Alokasi Dana Desa Pada Anggaran Pendapatan Dan Belanja Desa Tahun 2018 Di Desa Dawan Klod, Kecamatan Dawan, Kabupaten Klungkung. Jurnal Riset Akuntansi Warmadewa, 1(1), 15-20.

[18] Wibowo, A. S., \& Ghozali, I. (2018). Does value creation drive growth illusion? An evidence from Indonesia stock exchange. 